\title{
Biphasic Induction of Immediate Early Gene Expression Accompanies Activity- dependent Angiogenesis and Myofiber Remodeling of Rabbit Skeletal Muscle
}

Jeffrey B. Michel, * George A. Ordway, ${ }^{\star}$ James A. Richardson, ${ }^{5}$ and R. Sanders Williams ${ }^{\star 1 l}$

Departments of *Internal Medicine, "Biochemistry, ${ }^{\ddagger}$ Physiology, and ${ }^{8}$ Pathology, University of Texas Southwestern Medical Center, Dallas, Texas 75235

\begin{abstract}
Sustained contractile activity of skeletal muscle promotes angiogenesis, as well as transformation of contractile protein isoforms and mitochondrial proliferation within myofibers. Since the products of immediate early genes such as c-fos, c-jun, and egr-1 function in many signaling pathways governing cellular responses to external stimuli, we sought to determine whether sustained contractile activity induces their expression in skeletal muscle. Low voltage electrical stimulation was applied to the motor nerve innervating rabbit tibialis anterior muscles for periods ranging from 45 min to $21 \mathrm{~d}$. Northern and Western analysis demonstrated marked but transient inductions of c-fos, c-jun, and egr-1 mRNA and protein within the first $24 \mathrm{~h}$. Longer durations of stimulation were associated with a secondary and sustained rise in the abundance of $c-f o s, c-j u n$, and $p 88^{\mathrm{egr}-1}$ protein that, surprisingly, was not accompanied by detectable changes in mRNA. Immunohistochemistry demonstrated c-fos immunoreactivity within myofiber and vascular cell nuclei during both early and late phases of this response. These findings reveal a complex pattern of c-fos, c-jun, and egr-1 expression in response to nerve stimulation and suggest that these proteins could function in regulatory pathways that modify muscle phenotype. (J. Clin. Invest. 1994. 94:277-285.) Key words: c-fos • c-jun • proto-oncogenes $\cdot$ muscle $\cdot$ rabbits

\section{Introduction}

Contractile activity is a major determinant of the morphology and functional capabilities of skeletal muscle $(1,2)$. The consequences of physical inactivity contribute to morbidity associated with many human diseases (3) and, conversely, habitual exercise promotes salutary effects, some of which are attributable to adaptive responses of skeletal muscle (4). In previous studies (5-11) we have explored molecular mechanisms that control features of the adaptive responses of skeletal muscle to sustained contractile activity, but the potential contributions of immediate early genes to these processes have not been examined.

Chronic electrical stimulation of the rabbit tibialis anterior

Address all correspondence to R. Sanders Williams, Ryburn Center for Molecular Cardiology, University of Texas Southwestern Medical Center, NB11.200, 5323 Harry Hines Blvd., Dallas, TX 75235-8573.

Received for publication 2 December 1993 and in revised form 2 March 1994.

J. Clin. Invest.

(C) The American Society for Clinical Investigation, Inc.

0021-9738/94/07/0277/09 \$2.00

Volume 94, July 1994, 277-285
(TA ${ }^{1}$ muscle via the motor nerve causes transformation of skeletal myofibers from a fast-glycolytic to a slow-oxidative phenotype and stimulates capillary proliferation $(12,13)$. In response to this stimulus, genes encoding proteins involved in oxidative metabolism are induced while those encoding glycolytic enzymes are downregulated $(5,7,10)$. These effects are followed, in turn, by a switch to expression of slow/cardiac isoforms of proteins of the contractile apparatus (14). Morphologically, the fractional volume of mitochondria within myofibers is increased up to 10-fold, and an angiogenic response augments capillary density to a similar extent $(12,15)$. The physiological consequences of these adaptations render the muscle resistant to fatigue during sustained contractile work. Qualitatively similar, but lesser, effects on mitochondrial content and capillary density of skeletal muscles can be produced by endurance exercise training $(1,2)$, though the profound transformation of contractile protein isoforms produced by nerve stimulation is usually not observed.

The signaling pathways responsible for these pleiotropic adaptations are, however, poorly understood. Intracellular messengers such as cyclic AMP and calcium, and peptide signaling molecules such as basic fibroblast growth factor are increased in skeletal muscle following the onset of continuous nerve stimulation $(8,9,12-17)$, but the events that transduce signals arising within contracting muscles to the relevant genes are unknown. Based on their important role in controlling a wide variety of cellular responses to external and internal stimuli, we reasoned that products of immediate early genes such as c-fos, c-jun and $e g r-1$ were likely to be involved as third messengers in one or more of the adaptive responses induced by neural activity and contractile work in skeletal muscle.

The proto-oncogene products $\mathrm{c}$-fos and c-jun form dimers through leucine zipper domains to bind AP-1 sites within certain promoters $(18,19)$. The egr-1 gene encodes a single mRNA which is translated into two proteins $\mathrm{p} 88^{\text {egr-1 }}$ and $\mathrm{p} 82^{\text {egr-1}}$. The larger form results from translational initiation at an ACG site upstream of the canonical AUG site but is otherwise identical to $\mathrm{p} 82^{\text {egr-1 }}$. Both forms are detected in cells following treatment with phorbol ester though p88 ${ }^{\text {egr-1 }}$ is found in lower abundance relative to $p 82^{\text {egr-1 }}(20,21,22)$. c-fos and c-jun play an important role in many cell lineages to modulate cellular growth and differentiation during development, and in response to physiological stimuli $(18,23)$. The egr-1 gene is activated during differentiation of nerve and bone cells $(24,25)$ and appears to be required for differentiation of myeloid precursor cells to macrophages (26). Immediate early genes also are implicated in the hypertrophic response of cardiac myocytes to pressure

1. Abbreviations used in this paper: DAB, 3,3'-diaminobenzidine; GAPDH, glyceraldehyde 3-phosphate dehydrogenase; NADH-DH, NADH dehydrogenase; TA, tibialis anterior. 
overload $(27,28)$ and in cellular responses to acidosis, ATP depletion, and oxidative stress (29-31).

We observed in this study that c-fos, c-jun, and egr-1 mRNA and proteins are transiently induced in skeletal muscle within the first $24 \mathrm{~h}$ after the onset of continuous motor nerve stimulation. Elevated levels of c-fos immunoreactivity were present in both myofibers and vascular cells of the stimulated muscle. With more prolonged stimulation up to $21 \mathrm{~d}$, which is necessary to induce the mitochondrial biogenesis, fiber-type transformation, and angiogenesis that constitute the major adaptive responses to this stimulus, we observed a second induction of $\mathrm{c}$-fos, c-jun, and $\mathrm{p} 88^{\text {egr-1 }}$ protein. Late accumulation of $\mathrm{c}$-fos immunoreactivity was also present within nuclei of both myofibers and vascular cells. In contrast to the acute and transient induction observed during the first day, however, the subsequent increase in c-fos, c-jun, and p88 ${ }^{\text {egr-1 }}$ protein was sustained over several weeks, and was unaccompanied by detectable levels of mRNAs encoding these proteins by Northern analysis. These results implicate immediate early genes in signal transduction pathways triggered by neural activity and resulting in angiogenesis and fiber-type transformation in skeletal muscle. In addition, these data suggest the existence of previously unrecognized posttranscriptional controls on expression of immediate early genes during responses to physiological inputs.

\section{Methods}

Animal surgery and preparation. Adult New Zealand white rabbits weighing $2.2-3.5 \mathrm{~kg}$ were anesthetized by isoflurane inhalation. Under sterile conditions, pulse generators were implanted and their electrodes placed adjacent to the common peroneal nerve of one hindlimb according to the procedure described originally by Salmons and Vrbová (32). Electrical leads were sutured in place and care was taken to avoid injury to the nerve. Short-term nerve stimulation at $6-10 \mathrm{~Hz}$ was conducted for $0.75,2,4,8,12$, and $24 \mathrm{~h}$. Long-term stimulation at the same frequency was carried out for 7,14 , and $21 \mathrm{~d}$. The TA muscle itself was never instrumented. Harvested muscle tissue was rinsed in cold sterile saline and either cut in cross section for immunohistochemistry or frozen in liquid nitrogen and stored at $-80^{\circ} \mathrm{C}$ until processed for protein and RNA analyses. All protocols were approved by the Institutional Animal Care and Research Advisary Committee and were conducted in accordance with NIH Guide for the Care and Use of Laboratory Animals.

RNA analysis. Total RNA was extracted from tissue samples by homogenization of frozen sections of TA muscle weighing 0.4-0.5 grams in $10 \mathrm{ml}$ of RNA STAT-60 (Tel-Test "B," Inc., Friendswood, TX). After complete homogenization of the tissue, samples were placed at room temperature for $5 \mathrm{~min}$. Chloroform $(2 \mathrm{ml})$ was then added, samples were shaken vigorously for $15 \mathrm{~s}$, and allowed to stand at room temperature for 2-3 min. Samples were then centrifuged at $12,000 \mathrm{~g}$ for $15 \mathrm{~min}$ at $4^{\circ} \mathrm{C}$ and the top, clear aqueous phase removed. Isopropyl alcohol $(6 \mathrm{ml})$ was added and samples were allowed to stand for 5-10 min at room temperature before being centrifuged at $12,000 \mathrm{~g}$ for 10 min at $4^{\circ} \mathrm{C}$. RNA pellets were resuspended in 100-200 $\mu$ l DEPC-treated water. RNA concentrations were determined spectrophotometrically from absorbance at $260 \mathrm{~nm}$.

Northern blots of $10 \mu \mathrm{g}$ total RNA per lane were prepared on Hybond-N+ Membranes (Amersham, Arlington Heights, IL) by capillary blotting following electrophoresis in formaldehyde-agarose gels. RNA was immobilized by photocrosslinking (Stratalinker; Stratagene, La Jolla, CA). Blots were prehybridized overnight at $42^{\circ} \mathrm{C}$ in a solution of $50 \%$ deionized formamide, $4 \times$ SSC $(1 \times$ SSC $=150 \mathrm{mM}$ sodium chloride, $15 \mathrm{mM}$ sodium citrate), $5 \times$ Denhardt's solution $(0.1 \%$ each of bovine serum albumin, polyvinylpyrrolidone, and ficoll), $0.1 \mathrm{mg} / \mathrm{ml}$ salmon sperm DNA, $50 \mathrm{mM}$ sodium phosphate, $\mathrm{pH} 7.0,0.5 \mathrm{mg} / \mathrm{ml}$ sodium pyrophosphate and $1 \%$ SDS. Hybridizations were carried out overnight in hybridization solution (prehybridization solution with $1 \times$ Denhardt's solution) at $42^{\circ} \mathrm{C}$ using the appropriate cDNA probe at a final concentration of $0.5-1.0 \times 10^{7} \mathrm{cpm} / \mathrm{ml}$. Probes were ethanol precipitated and only probes with specific activities greater than $1.0 \times 10^{9}$ $\mathrm{cpm} / \mu \mathrm{g}$ were used. Filters were washed in $0.1 \times \mathrm{SSC}, 0.1 \%$ SDS at room temperature for $30 \mathrm{~min}$ followed by $30 \mathrm{~min}$ in $0.1 \times \mathrm{SSC}, 0.1 \%$ SDS at $55-65^{\circ} \mathrm{C}$. Filters were placed on film (Amersham HyperfilmMP) and exposed for 12-96 h.

c-fos mRNA was detected using a 480-bp probe from exon IV, a region with little homology to $f o s-B$ or $f r a-1$, obtained by Polymerase Chain Reaction (PCR) using genomic rabbit DNA as the template and the following primers: forward-5'-CCGAATTCGGCTTCCCAGAGGAGATGTCT-3'; reverse-5'-GGCTGCAGCAGCTNGGGAAGGAGTCAGC-3'. The product was subcloned into EcoRI and PstI sites of pGEM $4 \mathrm{Z}$ and the resulting plasmid was termed pGEM4.FOS. Sequencing of this fragment showed $>90 \%$ identity to published rat, murine and human c-fos nucleotide sequences, and $100 \%$ identity of the predicted amino acid sequence within this region. An EcoRI fragment of the plasmid JAC.1 (33) obtained from the American Type Culture Collection (ATCC, Rockville, MD) was used to detect c-jun mRNA. egr-1 message was detected using a 300-bp BglII/Rsa fragment from nucleotides 1958-2253 in the non-zinc-finger portion of the murine cDNA (pB700-3.6 ${ }^{-}$, a kind gift of V. Sukhatme, U. Chicago) (34). A 1.1-kb Human Glyceraldehyde 3-Phosphate Dehydrogenase (GAPDH) cDNA (Clonetech, Palo Alto, CA) was used to detect GAPDH mRNA.

All cDNA probes were labeled with (alpha- $\left.{ }^{32} \mathrm{P}\right) \mathrm{dATP}(6,000 \mathrm{Ci} /$ mmol) by random priming using a commercial kit (Pharmacia Fine Chemicals, Piscataway, NJ). The oligonucleotide probe complementary to 28S RNA, 5'-GGTCTAAACCCAGCTCACGTTC-3', was synthesized based on published sequences of murine 28S RNA. This oligonucleotide was end-labeled with (gamma- $\left.{ }^{32} \mathrm{P}\right) \mathrm{dATP}(6,000 \mathrm{Ci} / \mathrm{mmol})$ by T4 kinase.

Western analysis. Soluble protein extracts were prepared from muscle samples by homogenizing 0.4-0.5 $\mathrm{g}$ of frozen tissue in $2 \mathrm{ml}$ phosphate buffered saline, (PBS, $\mathrm{pH} 7.3$ ) followed by the addition of $2 \%$ Triton-X and the protease inhibitors, PMSF (20 $\mu \mathrm{l}$ of $0.1 \mathrm{mM}$ in ethanol), leupeptin ( $2 \mu \mathrm{l}$ of $5 \mathrm{mg} / \mathrm{ml}$ ), pepstatin $(2 \mu \mathrm{l}$ of $1 \mathrm{mg} / \mathrm{ml}$ in methanol), and aprotonin $(1 \mu \mathrm{lof} 10 \mathrm{mg} / \mathrm{ml})$. Samples were then homogenized a second time for $30 \mathrm{~s}$ and placed on ice for $5 \mathrm{~min}$. This homogenization was repeated three times. Samples were then centrifuged at $8,000 \mathrm{rpm}, 4^{\circ} \mathrm{C}$, for $15 \mathrm{~min}$ and the supernatant removed. Protein concentration was determined by the Bicinchonic Acid Method (35) (BCA assay; Pierce, Rockford, IL). Samples were heated at $95^{\circ} \mathrm{C}$ for $10 \mathrm{~min}$ in loading buffer ( $2 \times$ buffer $=20 \%$ glycerol, $125 \mathrm{mM}$ Tris base, $2 \%$ SDS, $2 \%$ 2-mercaptoethanol, $0.001 \%$ Bromophenol Blue, $\mathrm{pH}$ 6.8 ) before loading. Electrophoresis was carried out in $12 \%$ acrylamide gels containing SDS as described (36) using a Bio-Rad Mini-Protean II gel apparatus (Bio Rad Laboratories, Mellville, NY). One gel per experiment was stained with Coomassie blue to document equal loading (Staining solution: $0.05 \%$ Coomassie brilliant blue R, 50\% methanol, $10 \%$ Acetic Acid, $40 \% \mathrm{H}_{2} \mathrm{O}$; Destaining solution: $5 \%$ acetic acid, $16.5 \%$ methanol, 78.5\% $\mathrm{H}_{2} \mathrm{O}$ ). Protein was transferred to Hybond-N+ membranes (Amersham) using a Trans-Blot Electrophoretic Transfer Cell (Bio Rad Laboratories) following the manufacturer's instructions (electroblotting buffer: $20 \%$ methanol in $20 \mathrm{mM}$ Tris, $150 \mathrm{mM}$ glycine, $\mathrm{pH}$ 8.0). Membranes were incubated for $1 \mathrm{~h}$ in a solution of 5\% BSA or dry skim milk in PBS ( $\mathrm{pH} \mathrm{7.0)}$ ) prior to probing. Membranes were probed using 1:10,000 dilutions of the primary antibodies, followed by $1: 10,000$ dilutions of the appropriate species-specific secondary antibody congugated with horseradish peroxidase. The ECL detection system (Amersham) was then used and membranes were exposed to film for 120 min depending on the intensity of the signal. Films were subsequently scanned using a Molecular Dynamics 300A Computing Densitometer. (Molecular Dynamics, Inc., Sunnyvale, CA).

Integrated volumes were calculated for each band using Imagequant ${ }^{\mathrm{TM}}$ software (Molecular Dynamics, Inc.) following determina- 


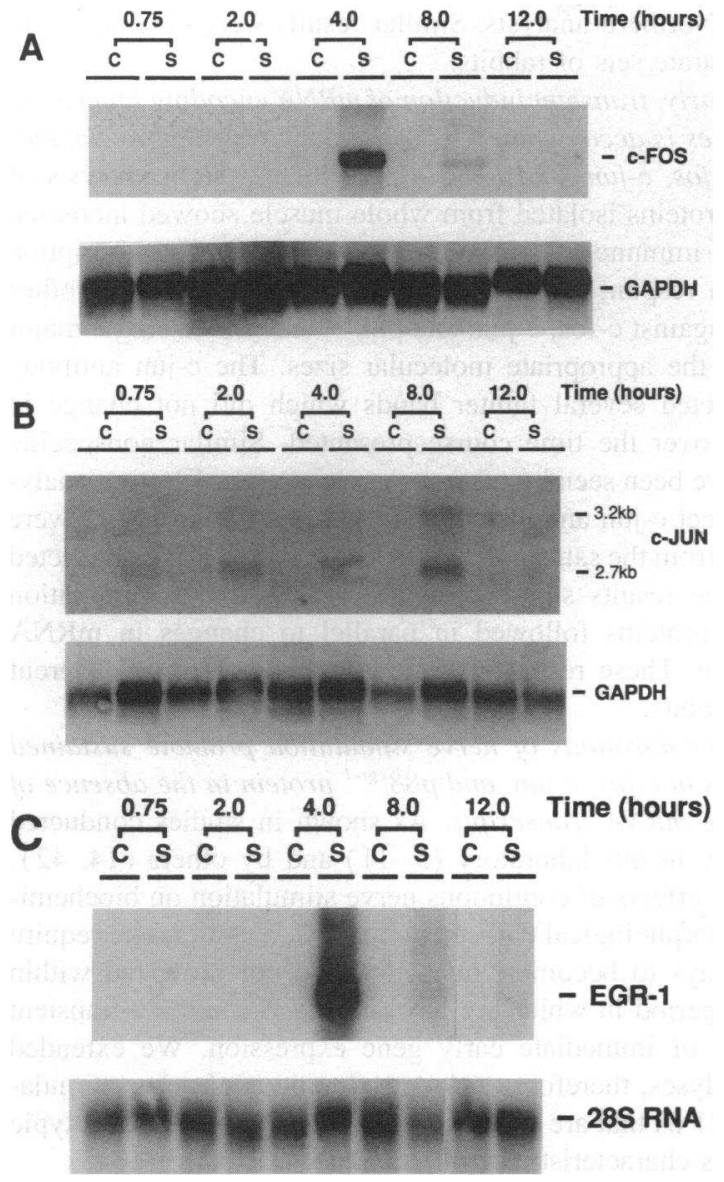

Figure 1. mRNA accumulation in response to short-term contractile activity. Total RNA ( $10 \mu \mathrm{g} /$ lane) from both stimulated $(S)$ and contralateral unstimulated $(C)$ TA muscle harvested after $0.75,2,4,8$, and $12 \mathrm{~h}$ of stimulation was probed with $(A) \mathrm{c}$ - fos cDNA, $(B) \mathrm{c}-j u n$ cDNA, or $(C)$ egr- 1 cDNA. Hybridization with c-fos and $e g r-1$ cDNAs produced single bands of correct size while c-jun cDNA probing produced two bands of 3.2 and $2.7 \mathrm{~kb}$. Blots were subsequently reprobed as shown to detect GAPDH mRNA or 28S rRNA to confirm the integrity of RNA samples and equivalent loading of individual lanes of each gel.

tion of, and correction for, background signal levels. Arbitrary Units (Arb units, Table I) equal the value obtained for each integrated volume.

Two different antibodies were used to detect c-fos immunoreactivity: a monoclonal antibody raised against amino acid residues 128 152 (37) (Ab-1; Oncogene Science Inc., Uniondale, NY) and rabbit polyclonal antibody raised against amino acid residues 3-16 (38) (Santa Cruz Biotechnology Inc., Santa Cruz, CA). c-jun and egr-1 protein was also detected using rabbit polyclonal antibodies (22) (Santa Cruz Biotechnology Inc.). The anti-egr-1 antibody sc-60 recognizes the $\mathrm{p} 88^{\text {egr-1 }}$ but not the $\mathrm{p} 82^{\text {egr-1 }}$ form of egr-1. Both $\mathrm{p} 88^{\text {egr-1 }}$ and $\mathrm{p} 82^{\text {egr- }}$ ${ }^{1}$ are products of the single mRNA species detected by northern analysis in this study and both forms are induced after phorbol ester treatment of cultured cells (22). These antibodies were chosen because of their specificity for the proteins of interest as reflected by the absence of cross-reactivity with related proteins, specifically fos-B, fra-1, jun-B, jun-D, and egr-2.

Immunohistochemistry. Small sections of freshly harvested TA muscle were quick-frozen in isopentane at $-70^{\circ} \mathrm{C}$, sectioned at $8 \mu \mathrm{m}$, fixed in acetone at $4^{\circ} \mathrm{C}$ for $10 \mathrm{~min}$ and quenched in $0.3 \% \mathrm{H}_{2} \mathrm{O}_{2}$ in $\mathrm{PBS}, \mathrm{pH}$ 7.3, for $30 \mathrm{~min}$. To detect c-fos, sections were incubated overnight at $4^{\circ} \mathrm{C}$ with either no primary antibody (PBS only) or the murine monoclonal antibody specific for $\mathrm{c}$-fos (Ab-1 referenced above) at 1:100 dilution
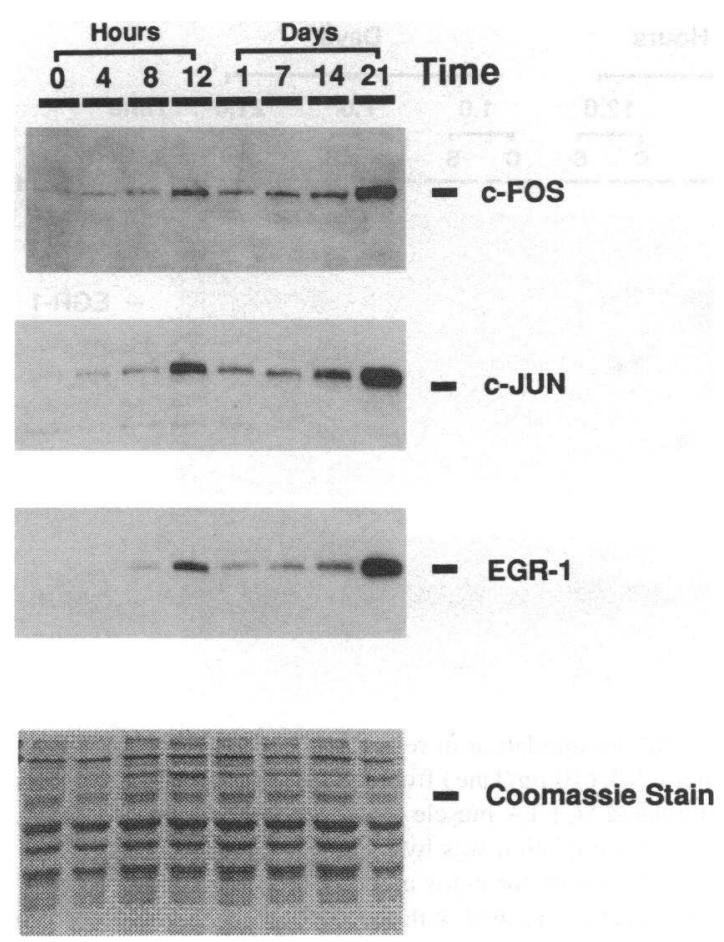

Figure 2. c-fos, c-jun, and $p 88^{e g r-1}$ protein accumulation in response to contractile activity. Rabbit polyclonal antibodies specific for c-fos (sc-52), c-jun (sc-45), and egr-1 (sc-60) were used to probe Western blots of soluble protein ( $10 \mu \mathrm{g} /$ lane $)$ obtained from TA muscle following 0 (control-unstimulated), 4, 8, 12, $24 \mathrm{~h}$ and 7, 14, and $21 \mathrm{~d}$ of continuous motor nerve stimulation. Coomassie blue staining of an acrylamide gel loaded with identical alliquots of soluble protein from each time point is shown as a control for both loading and protein integrity.

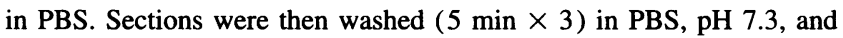
incubated with biotinylated horse anti-mouse IgG (Vector Laboratories, Inc., Burlingame, CA) for $1 \mathrm{~h}$. After washing again (in PBS, $5 \mathrm{~min}$ $\times 3$ ), slides were incubated with a complex of streptavidin and horse radish peroxidase (Vectastain ABC, Vector Laboratories, Inc.), washed, and finally incubated with a solution of 3,3'-diaminobenzidine + nickle (DAB, Vector). After $\sim 1-2 \mathrm{~min}$, sections were rinsed in $\mathrm{H}_{2} \mathrm{O}$, counterstained with eosin, dehydrated through serial ethanols, and mounted with permount. To detect endothelial cells, sections were incubated for $1 \mathrm{~h}$ at room temperature with a 1:30 dilution of mouse monoclonal antihuman CD31 antibody JC/70A (Dako Corp., Carpinteria, CA) (39) and processed as described for c-fos antibody.

NADH dehydrogenase and myosin ATPase. Muscle sections were stained for NADH dehydrogenase (DH) and Myosin ATPase using previously described methods (40). After NADH-DH staining, mitochondria-rich type I or type II oxidative fibers stain dark blue while glycolytic type II fibers are lighter. The distribution of mitochondria within myofibers also is visible with this stain. Myosin ATPase was detected following preincubation at $\mathrm{pH}$ 4.3. Preincubation at this $\mathrm{pH}$ results in dark brown staining of type I oxidative fibers and moderate staining of intermediate fibers (usually type IIc).

\section{Results}

Neural activity induces an acute, transient accumulation of $c$ fos, $c$-jun, and egr-1 mRNA. Northern analysis of total RNA obtained from stimulated and contralateral control TA muscle demonstrated a major accumulation of c-fos and egr-1 mRNA 


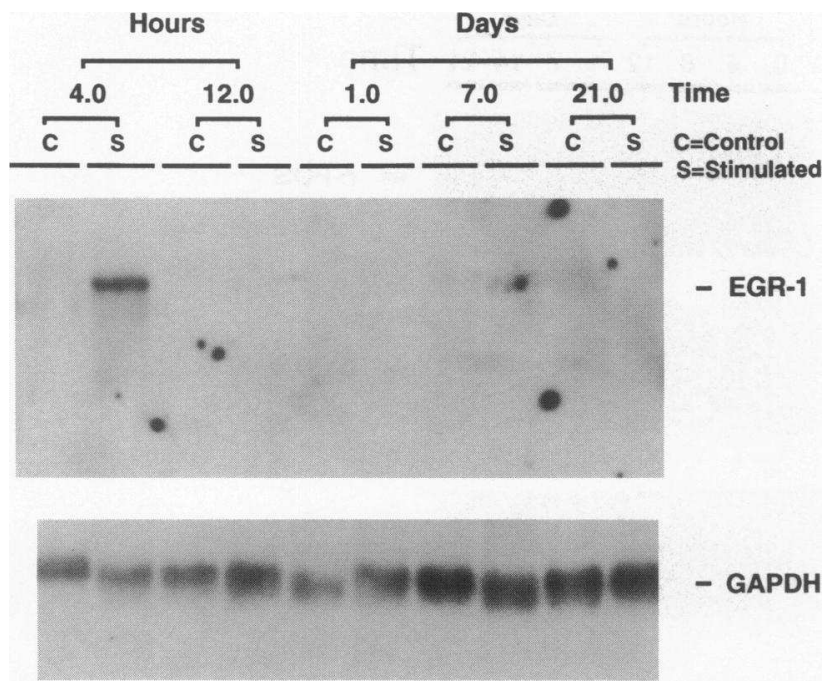

Figure 3. mRNA accumulation in response to long-term contractile activity. Total RNA ( $10 \mu \mathrm{g} /$ lane) from both stimulated $(S)$ and contralateral unstimulated $(C)$ TA muscle harvested following 4 and $12 \mathrm{hs,}$ 1,7 , and $21 \mathrm{~d}$ of stimulation was hybridized with the egr-1 cDNA. Similar results were seen for c-fos and c-jun (data not shown). This blot was subsequently reprobed with the GAPDH CDNA as shown to confirm RNA loading and integrity.

after $4 \mathrm{~h}$ of electrical stimulation of the motor nerve (Fig. 1, $A$ and $C$ ). This response abated quickly, however, and steadystate concentrations of these transcripts returned to baseline levels within 12-24 h. c-jun mRNA was detected earlier $(2 \mathrm{~h})$ after initiation of nerve activity and peaked later $(8 \mathrm{~h})$ (Fig. 1 $B)$. Like c-fos, egr-1 and c-jun mRNA levels returned to control levels by $24 \mathrm{~h}$. In contrast to these results, steady state concentrations of jun-D mRNA, a related proto-oncogene product, were not increased by motor nerve stimulation (data not shown). Ethidium bromide stains of gels before capillary transfer (not shown), and reprobing of blots for 28S RNA or GAPDH mRNA confirmed the integrity of each of these RNA samples and documented equivalent loading of each lane in gels used for Northern analysis. Similar results were obtained from three separate sets of rabbits.

The early, transient induction of $m R N A$ encoding immediate early genes is accompanied by a similarly transient accumulation of $c$-fos, $c$-jun, and $p 88^{\text {egr-1 }}$ proteins. Western analysis of soluble proteins isolated from whole muscle showed increased levels of immunoreactive proteins for all three transcription factors in response to nerve stimulation (Fig. 2). Antibodies directed against c-fos, c-jun, and p88 ${ }^{\mathrm{egr}-1}$ identified single major bands of the appropriate molecular sizes. The c-jun antibody also detected several fainter bands which did not change in intensity over the time course presented. Similar nonspecific bands have been seen by other researchers using Western analysis to detect c-jun antigen (41). Data presented in Fig. 2 were obtained from the same muscles from which RNA was extracted to produce results shown in Fig. 1. Thus, the accumulation of these proteins followed in parallel to changes in mRNA abundance. These results were reproducible in three different sets of rabbits.

Longer durations of nerve stimulation promote sustained elevations in c-fos, $c$-jun, and p88 $88^{\text {egr-1 }}$ protein in the absence of detectable mRNA transcripts. As shown in studies conducted previously in our laboratory $(5-11)$ and by others $(14,42)$, the major effects of continuous nerve stimulation on biochemical and morphological characteristics of skeletal muscle require several days to become evident and are not provoked within the time period in which we have observed acute but transient induction of immediate early gene expression. We extended these analyses, therefore, to longer durations of nerve stimulation (7-21 d) that are sufficient to induce the major phenotypic alterations characteristic of this model.

In muscles stimulated for 7-21 d $(n=3-5$ at each time point), immunoblots demonstrated a progressive and sustained increase in the abundance of c-fos, c-jun, or $\mathrm{p} 88^{\mathrm{egr}-1}$ proteins over this period (Fig. 2). In contrast to the first $24 \mathrm{~h}$, however, we detected no significant accumulation of c-fos, c-jun, or egr-1 mRNA at these later time points. Fig. 3 shows a representative Northern hybridization using the egr- $1 \mathrm{cDNA}$ probe. Total RNA from muscle stimulated for $4 \mathrm{~h}$ served as a positive control. Results of mRNA and protein measurements at early and late time points in the response to nerve stimulation are summa-

Table I. Effects of Stimulation on mRNA, Protein, and Citrate Synthase Activity

\begin{tabular}{|c|c|c|c|c|c|c|c|}
\hline & \multicolumn{3}{|c|}{ mRNA (Arb units) } & \multicolumn{3}{|c|}{ Protein (Arb units) } & \multirow[b]{2}{*}{ Citrate synthase } \\
\hline & c-fos & c-jun & egr-1 & c-fos & c-jun & egr-1 & \\
\hline & & & & & & & mmol/min/gram-muscle \\
\hline Control & ND & ND & ND & 8 & 5 & 8 & 6 \\
\hline $4 \mathrm{~h}$ & 610 & 43 & 820 & 12 & 9 & 11 & NA \\
\hline $8 \mathrm{~h}$ & 11 & 140 & 22 & 11 & 10 & 12 & NA \\
\hline $12 \mathrm{~h}$ & ND & ND & ND & 71 & 73 & 76 & NA \\
\hline $1 \mathrm{~d}$ & ND & ND & ND & 18 & 19 & 15 & 6 \\
\hline $7 \mathrm{~d}$ & ND & ND & ND & 35 & 24 & 32 & 13 \\
\hline $14 \mathrm{~d}$ & ND & ND & ND & 56 & 54 & 51 & 22 \\
\hline $21 \mathrm{~d}$ & ND & ND & ND & 400 & 229 & 184 & 36 \\
\hline
\end{tabular}

Arb units, arbitrary densitometry units from Northern and Western experiments as described in the text (see Methods), scaled so that the detection limit of the assay has a value of 1 . Densitometry values provide a semi-quantitative estimate of relative abundance. Protein and citrate synthase data are means of three separate experiments while only one representative Northern blot was quantified. $N D$, not detected; $N A$, not assessed. 

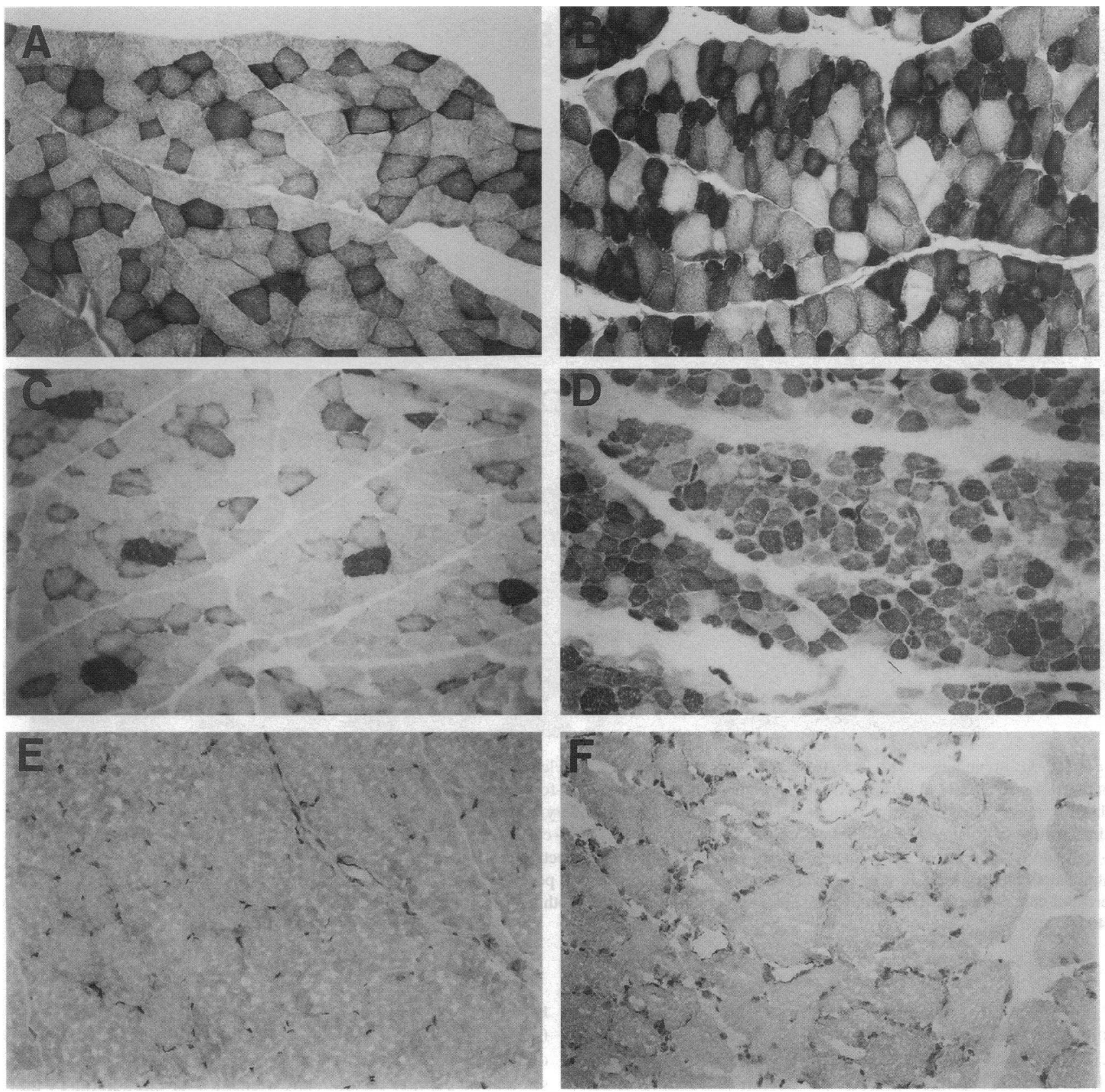

Figure 4. NADH-DH Myosin ATPase, histochemistry and CD-31 immunohistochemistry of control and 21-d stimulated muscle. 8- $\mu$ m sections of both unstimulated (control) and 21-d stimulated TA muscle were stained for either NADH-DH Myosin ATPase, or the endothelial cell specific antigen CD-31. $A, C$, and $E$ are sections of unstimulated muscle, while $B, D$, and $F$ are from TA muscle after $21 \mathrm{~d}$ of electrical stimulation. $A$ and $B$ were stained for NADH-DH. $C$ and $D$ were stained for myosin ATPase with preincubation at $\mathrm{pH}$ 4.3. Control muscle shows less staining for NADH-DH and much less Myosin ATPase staining than does 21-d stimulated muscle. $E$ and $F$ show results of immunohistochemistry using mouse monoclonal antibody JC/70A against the endothelial cell specific antigen CD-31. Note the prominent increase in endothelial cells between the myofibers of stimulated muscle as compared with control $(\times 100)$.

rized in Table I. Changes in citrate synthase activity provide a convenient biochemical marker for mitochondrial biogenesis in these muscles, and also progressed in our present experiments between 7 and $21 \mathrm{~d}$ of motor nerve stimulation (Table I), as we have observed previously $(5,7,10)$.

Increased expression of immediate early gene products occurs in both myofibers and vascular cells. TA muscles that had been stimulated for $12 \mathrm{~h}$ and $21 \mathrm{~d}$ were sectioned, along with control sections from unstimulated muscle. Fig. 4 demonstrates the striking changes in muscle phenotype that result from nerve stimulation, as reflected by changes in mitochondrial biogenesis (NADH dehydrogenase stain, Fig. $4, A$ and $B$ ), sarcomeric protein composition (myosin ATPase stain at $\mathrm{pH} \mathrm{4.3,} \mathrm{Fig.} \mathrm{4,} C$ and $D$ ), and angiogenesis (immunostain for CD-31 antigen, an endothelial cell marker, Fig. 4, $E$ and $F$ ).

Serial sections from the same muscles also were incubated with either PBS (control) or murine monoclonal antibody specific for c-fos (Ab-1). No nuclear staining was observed in 

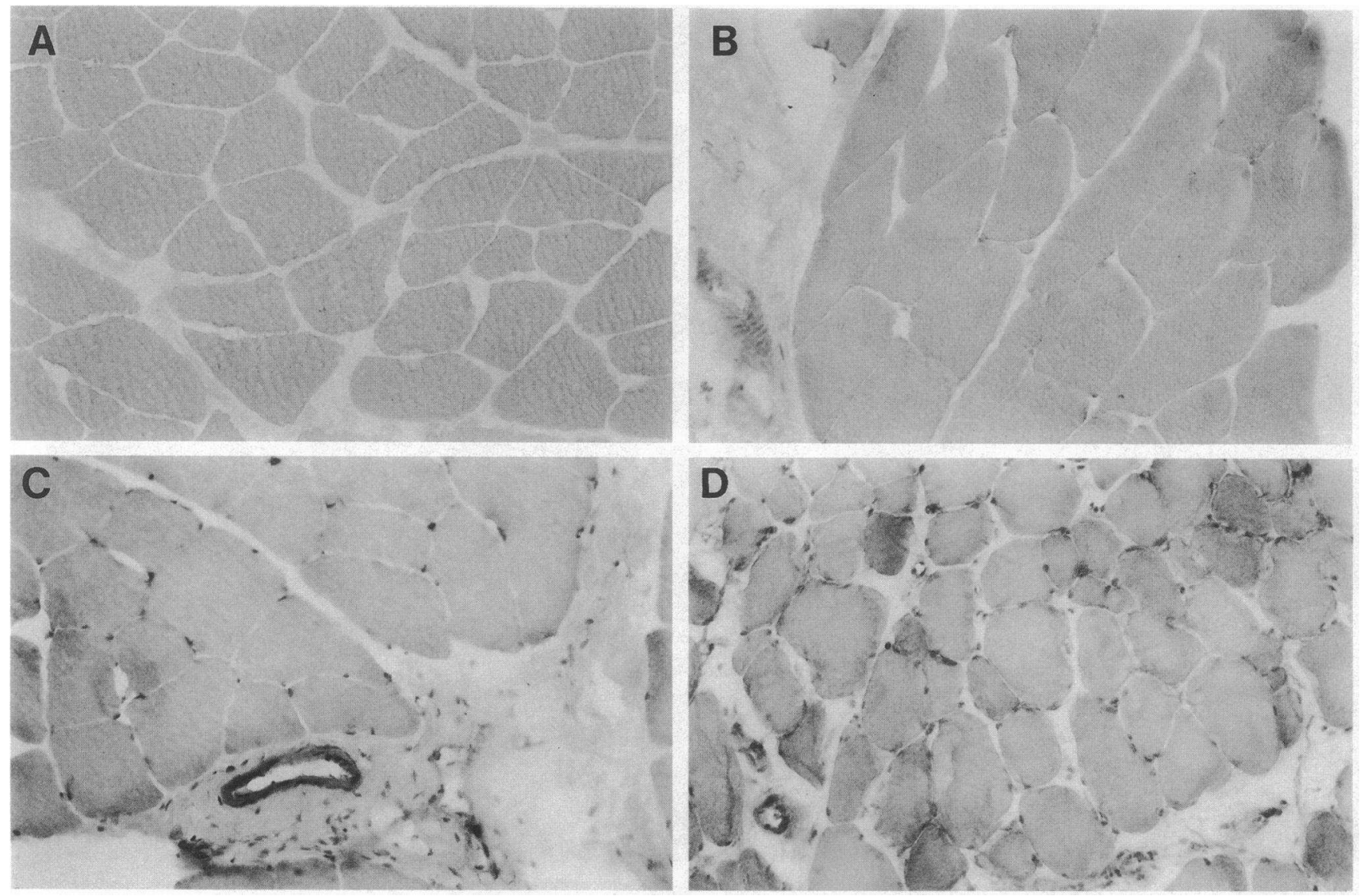

Figure 5. c- fos immunoreactivity in sections of control and stimulated muscles. 8- $\mu \mathrm{m}$ sections of control, unstimulated TA muscle and from muscles stimulated for $12 \mathrm{~h}$ or $21 \mathrm{~d}$ were incubated with mouse monoclonal anti-c-fos antibody Ab-1. One section of 21-d stimulated muscle not incubated with c-fos antibody but treated with biotinylated anti-mouse IgG secondary antibody, Streptavidin-HRP and DAB in parallel to the other sections to demonstrate that the nuclear DAB staining is specific and requires anti-c-fos antibody. $A$ shows this section. $B$ is control muscle treated with $\mathrm{Ab}-1$. $C$ and $D$ are sections of 12-h and 21-d stimulated TA muscle, respectively, treated with Ab-1. Only some sarcolemmal nuclei stain in unstimulated muscle. After $12 \mathrm{~h}$ of stimulation, most sarcolemal nuclei are positive and c-fos immunoreactivity is seen in nuclei within vessels and interstitial cells. After $21 \mathrm{~d}$ of stimulation, staining is prominent within both myofiber nuclei and within endothelial cell nuclei of neocapillaries $(\times 40)$.

the absence of specific antibody. Only occasional weak c-fos immunoreactivity was observed within vascular cell or myofiber nuclei in sections of unstimulated muscle, even after incubation with DAB for prolonged periods ( $>20 \mathrm{~min}$ ). Sections from muscle stimulated for $12 \mathrm{~h}$, however, demonstrated strong c-fos immunoreactivity within nuclei of both myofibers and vascular cells after only 1-2 min of DAB incubation (Fig. 5). Similar results were observed after $21 \mathrm{~d}$ of nerve stimulation, with strong nuclear staining within myofibers and blood vessels, as well as within proliferating capillary endothelial cells between myofibers (compare to the distribution of CD-31 antigen in Fig. 4).

\section{Discussion}

Immediate early genes are involved in signal transduction pathways that mediate cellular responses to external stimuli in many cell types. The induction of these genes by peptide growth factors that govern entry into the cell cycle and their role in proliferative growth of cells has received the most attention $(18,43)$, but immediate early genes also are implicated in differentiation events and physiological responses to hormones, neurotransmitters, other paracrine factors, or physical stresses (23-25, 29-31). In the mammalian heart, for example, immediate early genes are activated by pressure overload, mechanical stretch, or peptide factors (angiotensin II or endothelin-1) that result in hypertrophic rather than proliferative growth of cardiac myocytes $(27,28)$. Maneuvers that block induction of immediate early genes can suppress the hypertrophic response in cell culture models (44). A potential role for products of immediate early genes in activity-dependent remodeling events in skeletal muscle has not, however, been investigated previously in a systematic manner.

Phenotypic alterations in skeletal muscle that result from changes in contractile activity are a fundamental determinant of the enhanced endurance performance that results from exercise training $(1,2)$, and of the deleterious effects of prolonged bed rest or microgravity during space flight (45). In addition, activity-dependent changes in skeletal muscle have important pathophysiologic consequences in the natural history of several human disease states, including congestive heart failure and diabetes mellitus. Unlike the effects of pressure overload on cardiac muscle, tonic contractile activity of skeletal muscle does not lead to hypertrophy, but provokes a remodeling response char- 


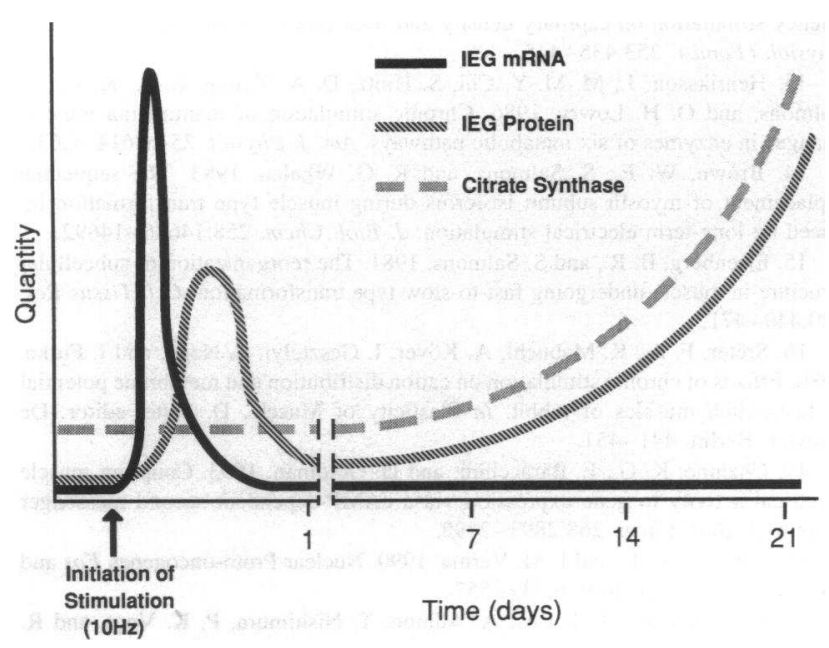

Figure 6. Schematic representation of changes in immediate early gene (IEG) mRNA and protein concentrations as a function of the duration of nerve stimulation. The biphasic nature of the accumulation of protein products of the immediate early genes c-fos, c-jun, and egr-l is illustrated by comparison to the transient acute induction of mRNA transcripts encoding these proteins, and to the progressive increase in citrate synthase enzymatic activity, a biochemical marker for the increased mitochondrial biogenesis that is one of the hallmarks of myofiber remodeling in this model. This schematic representation is based on data presented in Table I.

acterized by increased capillary density and mitochondrial proliferation within myofibers $(1,2)$. Chronic motor nerve stimulation of the tibialis anterior muscle in the rabbit provides a wellcharacterized experimental system for modeling these responses and for exploring their underlying mechanisms $(5-15,42)$. Qualitatively, the major remodeling events that result from endurance training in human or laboratory animals are recapitulated in this rabbit model. The effects on angiogenesis, mitochondrial proliferation, and fiber composition in this model are, however, quantitatively larger and occur in a more rapid and reproducible manner than in exercise training studies, and neural stimulation of one limb permits muscle from the contralateral limb to be used as a control. We chose this model, therefore, for analysis of activity-dependent changes in immediate early gene expression in skeletal muscle.

The major finding of this study is that skeletal muscle responds to continuous motor nerve activity with a significant, coordinated and biphasic induction of protein products of the immediate early genes c-fos, c-jun, and egr-1. As illustrated schematically in Fig. 6, an initial transient induction, characterized by large accumulations of mRNA within 4-8 $\mathrm{h}$ and peak protein levels by $12 \mathrm{~h}$, is seen during the first day after the initiation of stimulation. A later accumulation of these proteins follows, and is progressive and sustained, at least through 21 d. This secondary, sustained induction of products of immediate early genes occurs in parallel to the period of most rapid change in biochemical or histological markers of the major adaptive events that alter muscle phenotype. Both the acute and sustained phases of this response are evident within myofiber nuclei of the stimulated muscles as well as within nuclei of surrounding cells of the microvasculature. The underlying mechanisms of the early transient response differ from those of the later sustained response, in that the early induction appears to result primarily from transcriptional activation of these genes, while the later sustained response is dependent on translational or posttranslational mechanisms.

Several features of these activity-dependent responses of immediate early genes in skeletal muscle are distinctive, by comparison to previous studies of these genes in other cell types. When quiescent fibroblasts in culture are exposed to peptide growth factors, c-fos mRNA accumulation is detectable within 15-30 min and returns to baseline within several hours (23). In contracting skeletal muscle, however, several hours are required before accumulation of c-fos or egr-1 mRNA or protein is observed, even though severe perturbations of metabolites within the myofibers can be detected within minutes of the onset of nerve stimulation $(46,47)$. The molecular events that trigger increased expression of the c-fos, c-jun, and egr-l genes during neural stimulation of skeletal muscle resemble, therefore, the effects of serum on proliferating cells in culture in terms of the transient nature of the response and a dependence on transcriptional control. In the context of the intact muscle, however, transcriptional upregulation of immediate early genes takes longer to develop after the onset of the stimulus, suggesting a requirement for intermediate steps that remain to be identified.

Another distinctive feature of our current data is the late, sustained accumulation of immediate early gene proteins in skeletal muscle following chronic neural stimulation. In untransformed cells, the transient nature of immediate early gene activation has been an almost universal feature, irrespective of the inducing stimulus. Unregulated, sustained expression of vfos, the viral homologue of c-fos, results in malignant transformation, and sustained c-fos expression has been observed previously only as a marker for apoptosis during embryogenesis (48). Our results indicate, however, that sustained, high-level expression of c-fos can occur during adaptive responses to physiological stimuli under conditions in which neither malignant transformation nor programmed cell death is observed. It is also important to note that neither significant degeneration of myofibers nor inflammatory infiltrates were evident in chronically stimulated muscles that exhibited upregulation of immediate early genes. Thus, unlike in vivo models of hypoxic injury to brain or liver (49), increased expression of immediate early genes in our model is not occurring in irreversibly injured cells.

Two other features of the late, sustained elevation in c-fos protein in chronically stimulated skeletal muscles are of special interest. First, sustained elevation in nuclear c-fos immunoreactivity was present in both myofibers and vascular cells within the stimulated muscles. The significance of this finding is that this sustained response is present not only in cell types (vascular endothelium) undergoing proliferative growth in this model, but in postmitotic myofibers undergoing remodeling in the absence of proliferative growth. Second, in contrast to the acute, transient induction of immediate early genes noted in the first $24 \mathrm{~h}$ after the onset of nerve stimulation, the sustained accumulation of c-fos protein observed between 14 and $21 \mathrm{~d}$ in this model was unaccompanied by a detectable accumulation of steadystate c-fos mRNA. Rigorous positive controls support the validity of this unexpected finding. Perhaps more sensitive methods such as RNAse protection assays would demonstrate increased abundance of IEG mRNAs during this period by comparison to baseline levels, but such induction, if present, is clearly of a lesser magnitude than that observed during the early response to nerve stimulation. Significant upregulation of the abundance of protein products of immediately early genes without detect- 
able concomitant mRNA transcript accumulation has not been described in earlier studies, and suggests the existence of translational or posttranslational controls that have not been previously recognized.

In conclusion, our data demonstrate that the immediate early genes c-fos, c-jun, and egr-1 are induced in rabbit skeletal muscles subjected to chronic nerve stimulation. Increased accumulation of products of immediate early genes was evident within both myofibers and vascular cells and exhibited two phases: an early, transient induction of both mRNA and protein; and a late, sustained elevation of immunoreactive protein in the absence of detectable accumulation of mRNA. These data suggest a potential role for products of immediate early genes in the angiogenic response and in the remodeling of myofibers that are induced by neural activity in this model. In addition, these findings expand the repertoire of physiological stimuli that lead to up-regulation of immediate early gene expression and suggest the existence of novel mechanisms by which these important proteins are regulated.

\section{Acknowledgments}

The authors thank David Maass for his invaluable assistance with rabbit instrumentation and care. We also thank Randy Stephens and John Shelton for their expert assistance with tissue immunohistochemistry. In addition, both Gregory A. Hand and Dr. Rhonda Bassel-Duby provided valuable help with study design and manuscript preparation.

J. B. Michel is a scholar of the Sarnoff Endowment for Cardiovascular Science and received support from National Institutes of Health (NIH) training grant HL-07360. This work was also supported by NIH grants HL-06296 and AR-40849.

\section{References}

1. Holloszy, J. O. 1967. Biochemical adaptations in muscle: effects of exercise on mitochondrial oxygen uptake and respiratory enzyme activity in skeletal muscle. J. Biol. Chem. 242:2278-2282.

2. Saltin, B., and P. D. Gollnick. 1983. Skeletal muscle adaptability; significance for metabolism and performance. In Handbook of Physiology. Skeletal Muscle. E. Kandel, editor. Am. Physiol. Soc., Bethesda, MD. 555-632.

3. Paffenbarger, R. S., R. T. Hyde, A. L. Wing, I. M. Lee, D. L. Jung, and J. B. Kampert. 1993. The association of changes in physical-activity level and other lifestyle characteristics with mortality among men. N. Engl. J. Med. 328:538-545.

4. Minotti, J. R., E. C. Johnson, T. L. Hudson, G. Zuroske, G. Murata, E. Fukushima, T. G. Cagle, T. W. Chick, B. M. Massie, and M. V. Icenogle. 1990. Skeletal muscle response to exercise training in congestive heart failure. J. Clin. Invest. 86:751-758.

5. Williams, R. S., S. Salmons, E. A. Newsholme, R. E. Kaufman, and J. Mellor. 1986. Regulation of nuclear and mitochondrial gene expression by contractile activity in skeletal muscle. J. Biol. Chem. 261:376-380.

6. Williams, R. S. 1986. Mitochondrial gene expression in mammalian striated muscle: evidence that variation in gene dosage is the major regulatory event. $J$. Biol. Chem. 261:12390-12394.

7. Williams, R. S., M. Garcia-Moll, J. Mellor, S. Salmons, and W. Harlan. 1987. Adaptation of skeletal muscle to increased contractile activity. J. Biol. Chem. 262:2764-2767.

8. Kraus, W. E., T. S. Bernard, and R. S. Williams. 1989. Interactions between sustained contractile activity and beta-adrenergic receptors in regulation of gene expression in skeletal muscles. Am. J. Physiol. 256:C506-C514.

9. Morrow, N. G., W. E. Kraus, J. W. Moore, R. S. Williams, and J. L. Swain. 1990. Increased expression of fibroblast growth factors in a rabbit skeletal muscle model of exercise conditioning. J. Clin. Invest. 85:1816-1820.

10. Annex, B. H., W. E. Kraus, G. L. Dohm, and R. S. Williams. 1991. Mitochondrial biogenesis in striated muscles: rapid induction of citrate synthase mRNA by nerve stimulation. Am. J. Physiol. 260:C266-C270.

11. Ordway, G. A., K. Li, G. A. Hand, and R. S. Williams. 1993. The RNA subunit of a mitochondrial RNA processing (MRP) enzyme is induced by contractile activity in striated muscle. Am. J. Physiol.: Cell Physiol. 265:C1511-C1516.

12. Hudlicka, O., and K. R. Tyler. 1984. The effect of long-term high-fre- quency stimulation on capillary density and fiber types in rabbit fast muscles. $J$. Physiol. (Lond.). 353:435-445.

13. Henriksson, J., M. M.-Y. Chi, S. Hintz, D. A. Young, K. K. Kaiser, S. Salmons, and O. H. Lowry. 1986. Chronic stimulation of mammalian muscle: changes in enzymes of six metabolic pathways. Am. J. Physiol. 251:C614-C632.

14. Brown, W. E., S. Salmons, and R. G. Whalen. 1983. The sequential replacement of myosin subunit isoforms during muscle type transformation in duced by long-term electrical stimulation. J. Biol. Chem. 258:14686-14692.

15. Eisenberg, B. R., and S. Salmons. 1981. The reorganization of subcellular structure in muscle undergoing fast-to-slow type transformation. Cell Tissue Res. 220:449-471.

16. Sréter, F. A., K. Mabuchi, A. Köver, I. Gesztelyi, Z. Nagy, and I. Furka. 1980. Effects of chronic stimulation on cation distribution and membrane potential in fast-twitch muscles of rabbit. In Plasticity of Muscle. D. Pette, editor. De Gruyter, Berlin. 441-451.

17. Chahine, K. G., E. Baracchini, and D. Goldman. 1993. Coupling muscle electrical activity to gene expression via a cAMP-dependent second messenger system. J. Biol. Chem. 268:2893-2898.

18. Ransone, L. J., and I. M. Verma. 1990. Nuclear Proto-oncogenes Fos and Jun. Annu. Rev. Cell Biol. 6:539-557.

19. Bohmann, D., T. J. Bos, A. Admon, T. Nishimura, P. K. Vogt, and R. Tjian. 1987. Human proto-oncogene c-jun encodes a DNA-binding protein with structural and functional properties of transcription factor AP-1. Science (Wash. DC). 238:1386-1392.

20. Cao, X., R. A. Koski, A. Gashler, M. McKiernan, C. F. Morris, R. Gaffney, R. V. Hay, and V. P. Sukhatme. 1990. Identification and characterization of the egr-1 gene product, a DNA-binding zinc finger protein induced by differentiation and growth signals. Mol. Cell. Biol. 10:1931-1939.

21. Christy, B., and D. Nathans. 1989. DNA binding site of the growth factorinducible protein Zif268. Proc. Natl. Acad. Sci. USA. 86:8737-8741.

22. Lemaire, P., C. Vesque, J. Schmitt, H. Stunnenberg, R. Frank, and P. Charnay. 1990. The serum-inducible mouse gene krox-24 encodes a sequencespecific transcription factor. Mol. Cell. Biol. 10:3456-3467.

23. Sassone-Corsi, P., W. W. Lamph, and I. M. Verma. 1988. Regulation of proto-oncogene fos: a paradigm for early response genes. Cold Spring Harb. Symp. Quant. Biol. 53:749-760.

24. Milbrandt, J. 1987. A nerve growth factor-induced gene encodes a possible transcriptional regulatory factor. Science (Wash. DC). 238:797-799.

25. Suva, L. J., M. Ernst, and G. A. Rodan. 1991. Retinoic acid increases Zif268 early gene expression in rat preosteoblastic cells. Mol. Cell. Biol. 11:25032510 .

26. Nguyen, H. Q., B. Hoffman-Liebermann, and D. A. Lieberman. 1993. The zinc finger transcription factor egr-1 is essential for and restricts differentiation along the macrophage lineage. Cell. 72:197-209.

27. Izumo, S., B. Nadal-Ginard, and V. Mahdavi. 1988. Proto-oncogene induction and reprogramming of cardiac gene expression produced by pressure overload. Proc. Natl. Acad. Sci. USA. 85:339-343.

28. Sadoshima, J., and S. Izumo. 1993. Mechanical stretch rapidly activates multiple signal transduction pathways in cardiac myocytes: potential involvement of autocrine/paracrine mechanism. EMBO (Eur. Mol. Biol. Organ.) J. 12:16811692.

29. Isfort, R. J., D. B. Cody, T. N. Asquith, G. M. Ridder, S. B. Stuard, and R. A. Leboeuf. 1993. Induction of protein phosphorylation, protein synthesis, immediate-early gene expression and cellular proliferation by intracellular $\mathbf{p H}$ modulation. Eur. J. Biochem. 213:349-357.

30. Uemura, Y., N. W. Kowall, and M. A. Moskowitz. 1991. Focal ischemia in rats causes time-dependent expression of c-fos protein immunoreactivity in widespread regions of ipsilateral cortex. Brain Res. 552:99-105.

31. Rao, G. N., and B. C. Berk. 1992. Active oxygen species stimulate vascular smooth muscle cell growth and proto-oncogene expression. Circ. Res. 70:593599.

32. Salmons, S., and G. Vrbová. 1969. The influence of activity on some contractile characteristics of fast and slow muscles. J. Physiol. (Lond.) 201:535549.

33. K. Ryder, and D. Nathans. 1988. Induction of protooncogene c-jun by serum growth factors. Proc. Natl. Acad. Sci. USA. 85:8464-8467.

34. Sukhatme, V. P., X. Cao., L. C. Chang, C.-H. Tsai-Morris, D. Stamenkovich, P. C. P. Ferreira, D. R. Cohen, S. A. Edwards, T. B. Shows, T. Curran, M. M. LeBeau, and E. D. Adamson. 1988. A zinc finger encoding gene coregulated with c-fos during growth and differentiation, and after cellular depolarization. Cell. 53:37-43.

35. Smith, P. K., R. I. Krohn, G. T. Hermanson, A. K. Mallia, F. H. Gartner, E. K. Fujimoto, N. M. Goeke, B. J. Olson, and D. C. Klenk. 1985. Measurement of protein using bichinchonic acid. Anal. Biochem. 150:76-85.

36. Smith, J. A. 1993. One dimensional electrophoresis of proteins In Current Protocols in Molecular Biology. F. M. Ausubel, R. Brent, R. E. Kingston, D. D. Moore, J. G. Seidman, J. A. Smith, and K. Struhl, editors. John Wiley \& Sons, Inc., New York. Section 10.2.

37. Giardina, S. L., S. W. Evans, L. Gardino, F. A. Robey, E. Bonvin, D. L. 
Longo, and L. Varesio. 1987. Generation of a murine monoclonal antibody that detects the $f$ os oncogene product. Anal. Biochem. 161:109-116.

38. Sambucetti, L. C., and T. Curran. 1986. The fos protein complex is associated with DNA in isolated nuclei and binds to DNA cellulose. Science (Wash. DC). 234:1417-1419.

39. Parums, D. V., J. L. Cordell, K. Micklem, A. R. Heryet, K. C. Gatter, and D. Y. Mason. 1990. JC70: a new monoclonal antibody that detects vascular endothelium associated antigen on routinely processed tissue sections. J. Clin. Pathol. 43:752-757.

40. Dubowitz, V., M. H. Brooke, and H. E. Neville. 1973. Muscle Biopsy: a Modern Approach. J. N. Walton, editor. W. B. Saunders Co. Ltd., Philadelphia, PA. 475pp.

41. Thinakaran, G., J. Ojala, and J. Bag. 1993. Expression of c-jun/AP-1 during myogenic differentiation in mouse c2c12 myoblasts. FEBS (Fed. Eur Biochem. Soc.) Lett. 319:271-276.

42. Pette, D., and G. Vrbová. 1992. Adaptation of mammalian skeletal muscle fibers to chronic electrical stimulation. Rev. Physiol. Biochem. Pharmacol. 120:115-203.

43. L. D. Kerr, J.-I. Inoue, and I. M. Verma. 1992. Signal transduction: the nuclear target. Curr. Opin. Cell Biol. 4:496-501.
44. Neyses, L., J. Nouskas, and H. Vetter. 1991. Inhibition of endothelin-1 induced myocardial protein synthesis by an antisense oligonucleotide against early growth response gene-1. Biochem. Biophys. Res. Commun. 181:22-27.

45. Rabin, R., S. L. Gordon, R. W. Lymn, P. W. Todd, M. A. Frey, and F. M. Sulzman. 1993. Effects of spaceflight on the musculoskeletal system: NIH and NASA future directions. FASEB (Fed. Am. Sec. Exp. Biol.) J. 7:396-398.

46. Green, H. J., J. Cadefau, and D. Pette. 1991. Altered glucose 1,6-bisphosphate and fructose 2,6-biphosphate levels in low-frequency stimulated rabbit fasttwitch muscle. FEBS (Fed. Eur. Biochem. Soc.) Lett. 282:107-109.

47. Pette, D., S. Dusterhoft, H. J. Green, S. Hofman. 1991. Early metabolic events in chronic stimulation induced fast to slow transitions. In Basic and Applied Myology: Perspectives for the 90's. U. Carrano and S. Salmons, editors. Unipress, Padova. 55-62.

48. Smeyne, R. J., M. Vendrell, M. Hayward, S. J. Baker, G. G. Miao, K. Schilling, L. M. Robertson, T. Curran, and J. I. Morgan. 1993. Continuous c-fos expression precedes programed cell death in vivo. Nature (Lond.). 363:166-169.

49. Dragunow, M., D. Young, P. Hughes, G. MacGibbon, P. Lawlor, K Singelton, E. Sirmanne, E. Beilharz, and P. Gluckman. 1993. Is c-jun involved in nerve cell death following status epilepticus and hypoxic-ischaemic brain injury? Brain Res. 18:347-352. 